\section{OPEN JOURNAL SYSTEMS}

ISSN:2237-2202
Available on line at Directory of Open Access Journals

Journal of Hyperspectral Remote Sensing v.9, n.4 (2019) 217-227

www.periodicos.ufpe.br/revistas/jhrs

\section{Journal of Hyperspectral Remote Sensing \\ www.ufpe.br/jhrs}

\title{
Characterization of the Soil Temperature Using Wavelets in two Forest Biomes: Amazonas and Atlantic Florets
}

\author{
Rayonil G. Carneiro", Marcos A. L. Moura ${ }^{* *}$, Vicente de P. R. da Silva ${ }^{* * *}$, Camilla K. Borges ${ }^{* * *}$, Gilberto Fisch ${ }^{* * * *}$ \\ * Instituto Nacional de Pesquisas Espaciais, São José dos Campos-SP, Brasil. E-mail: rayonilcarneiro@ gmail.com \\ (Corresponding author) \\ *** Instituto de Ciências Atmosféricas, Universidade Federal de Alagoas, Maceió-AL, Brasil. \\ **** Unidade de Ciências Atmosféricas, Universidade Federal de Campina Grande, Campina Grande-PB, Brasil. \\ ***** Universidade de Taubaté, Taubaté - SP, Brasil.
}

Received 21 August, accepted 31 October 2019

\begin{abstract}
This study aimed to evaluate and compare the seasonal and spatial profiles of soil temperature (ST) in the biomes of the Amazon Forest and Atlantic Forest, using the wavelet transform. In the Amazon rainforest were used the data from the year 2009. In the Atlantic Forest used up to year 2010 data. The results showed that the ST in the Amazon rainforest shows little variation in time with temperature range below $5{ }^{\circ} \mathrm{C}$. In the rainforest, this exhibited high thermal amplitude throughout the year, more than $10^{\circ} \mathrm{C}$. The wavelet transform showed that the variability of ST is defined by multi-scale time: 24 hours for both biomass, 8 to 16 days for Amazon and 4 to 16 days to Atlantic forest.
\end{abstract}

Keywords: rainforest, precipitation, time series

\section{Introduction}

The spatio-temporal variations of soil temperature (ST) influence biological and chemical processes, decomposition and mineralization rates of organic matter and $\mathrm{CO}_{2}$ release, particularly in tropical forests (Graham et al., 2010; Onwuka, 2016). The ST determines evaporation and aeration levels, and their variation is critical in ecological development, as it directly interferes with plant germination and growth, as well as water and nutrient absorption (Awe et al., 2015; Wang et al., 2016).

The dynamics of soil temperature is fundamental in the development ecological since its variation directly affects the germination and plant growth, as well as the absorption of water and nutrients (Qian et al., 2011). In this respect, ST is of fundamental importance because it influences seed germination, root development and activity in absorbing water and nutrients from the soil, the activity of microorganisms, the diffusion of solutes and gases, the development of diseases and speed of soil chemical reactions. Moreover, this variable is also an important indicator of climate change and an essential parameter for geotechnical and geotechnology engineering, as well as the physical, biological and chemical soil (Park et al., 2018).

Tropical forests play an important role in maintaining regional and global climate, directly influencing the emission or retention of gases, evapotranspiration and water vapor supply, among other factors. These biomes, due to their humidity and heat conditions, are the terrestrial ecosystems that have the greatest diversity of living beings. The Amazon rainforest and the Atlantic rainforest of Brazil have the largest biodiversity in the country (Ledru et al., 2005).

The Amazon biome to be the largest area of tropical forest in the world, accounting for $28 \%$ of global tropical forests, contains 15 to $20 \%$ of water and about one third of all the planet's biodiversity (Freitas and Castro Jr, 2004). This biome is important for the absorption of carbon dioxide from the atmosphere, and vegetation through photosynthesis absorbs approximately 1.2 billion tons of carbon dioxide per year. Deforestation of the Amazon rainforest has already reached $17 \%$. Just considering the last twenty years, $360,000 \mathrm{~km} 2$ of forest have been devastated, which corresponds to the Goiás State area (INPE, 2016). Deforestation occurs for the establishment of pastures for cattle raising, soybean planting and logging.

The Atlantic Forest biome, which is a complex and exuberant set of ecosystems of recognized national and international importance in the scientific environment, is represented by various types of vegetation such as Dense, Mixed and Open Ombrophiles Forests; Seasonal Deciduous and 
Semideciduous Forest; Mangrove; Altitude Fields; Inland swamps and ecological stress zones, thus sheltering a significant portion of Brazil's biodiversity. It is currently very fragmented; whose fragmentation is the main cause of biodiversity loss (INPE/SOS ATLANTIC FOREST, 2016). In the Atlantic Forest Remnant Atlas (2011 - 2016) data, it is estimated that currently the domain of the remaining Atlantic forest is only $95,000 \mathrm{~km}^{2}$, about $7.3 \%$ of the original area.

The wavelet transform (WT) is a timefrequency tool capable of detecting energy variations within meteorological data (Chellali et al., 2010). It is very suitable for analyzing meteorological time series containing information on different time scales, such as diurnal, seasonal and annual scales.

The complex interaction between soil, vegetation and atmosphere needs to be well understood, aiming at contributing to meteorological studies, as well as the natural physical processes occurring in the region. Given the relevance of studies of soil thermal behavior within distinct forest regions and the scarcity of this type of study, the present study aimed to evaluate and compare, through the application of the Wavelet Transform (WT) the soil temperature (ST) variability scales within two biomes, Amazon and Atlantic rainforest.

\section{Material and methods}

\section{Experimental Area I (Amazon Forest)}

The experimental area $I$ is located at $\left(2^{\circ} 35^{\prime}\right.$ 22"S, 60 $00^{\circ}$ ' 55"W) in the Cueiras Biological Reserve (Figure 1). This area belongs to National Amazon Research Institute (INPA), located approximately $60 \mathrm{~km}$ north to the city of Manaus (AM), capital of Amazonas state. The site has an area of 22,735 ha and is part of a larger portion of native forest (Chellali et al., 2010). The access is via a not all paved road ZF-2 (Marques Filho et al., 2005).
The relief of the Cuieiras Biological Reserve is strongly undulating and has its drainage network between plateaus (higher areas of the topography) and shoals (lower areas of the topography). In the shoals several streams appear forming a rich flow network, with maximum height difference between plateaus and shoals of approximately $60 \mathrm{~m}$. The plateau is covered by Yellow Alic Latosol (Oxisol), with clayey, poor in nutrients (Malhi et al., 2002). While the shoal is essentially composed of sandy soil (Marques Filho et al., 2005). The experimental site is a typical area of undisturbed primary tropical vegetation, with a canopy ranging from $30-40 \mathrm{~m}$.

The climate of central Amazonia is characterized by high temperature and humidity, with abundant rain during the year $\left(2.300 \mathrm{~mm}_{\text {year }}{ }^{-1}\right)$ and a short dry period. The average annual temperature is $26.7^{\circ} \mathrm{C}$. The rainy season lasts from December to May, while the driest season usually lasts from June to September.

The meteorological variables that have been monitored in this experiment are those measured by automatic weather stations (AWS) under the supervision of the micrometeorological group of the Large Scale Biosphere-Atmosphere Experiment in Amazonia (LBA).

The instruments are installed in a micrometeorological tower known as K34 which has an aluminum structure $(1,5 \mathrm{~m} \times 2,54 \mathrm{~m}$ of cross section e $54,0 \mathrm{~m}$ high) in a region of mesas $\left(2^{\circ} 36^{\prime}\right.$ 32 " S, $60^{\circ} 12^{\prime} 33^{\prime \prime} \mathrm{W}$ ), at kilometer 34 of the ZF-2.

The analyzes of soil temperature profile (ST) were performed at depths 2, 5, 10, 20 and $50 \mathrm{~cm}$ deep using MCM 101 sensors (IMAG-DLO, Wageningen, Netherlands) installed in the base of the tower. Measurements for these depths were used from January to December 2009.

Rainfall totals were collected by ARG100 aerodynamic rain gauges from Environmental Measurements Ltd. (North Shields, UK). 


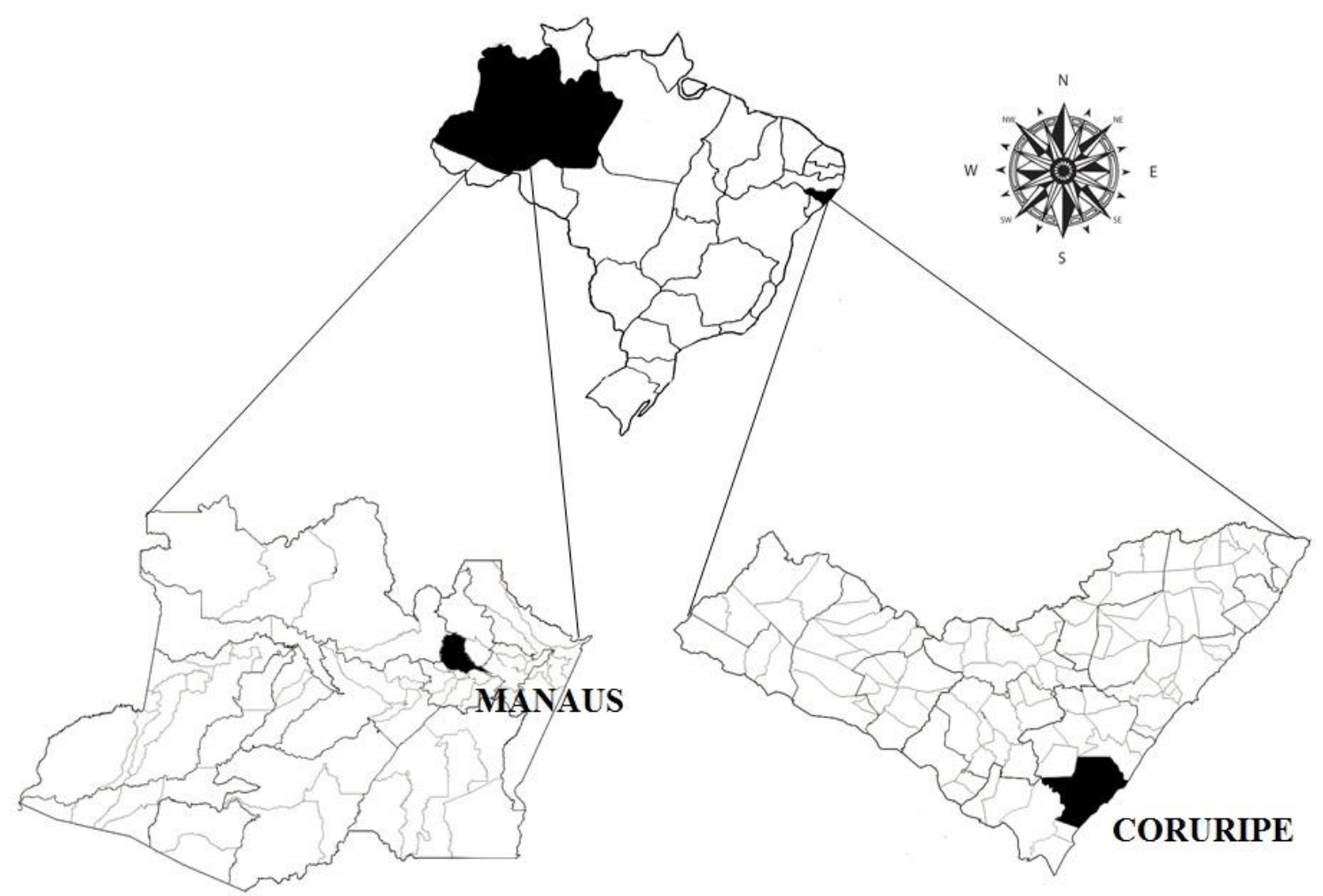

Figure 1 - Geographical location of the study areas, especially in the city of Manaus, Amazon and Coruripe, Alagoas.

\section{Experimental Area II (Atlantic Forest)}

Experimental Area II (1000' $37^{\prime \prime} \mathrm{S}, 36^{\circ} 17^{\prime}$

$\left.60^{\prime \prime} \mathrm{W}\right)$ is located in a fragment of Atlantic Forest belonging to the Private Natural Heritage Reserve (PNHR), with an area of 68.6 ha belonging to Sugar and Ethanol Coruripe S/A factory in the municipality of Coruripe, Alagoas (see Figure 1) (Carneiro et al., 2013). This PNHR is intended for seed collection for the recovery of the plant's degraded areas, for environmental education programs and for scientific research. Located on the southern coast of the State of Alagoas, the municipality of Coruripe presents forest fragments in the trays, steep slopes and few floodplain areas in which it is formed by an Open Ombrophilous Forest with transition to Semideciduous Seasonal Forest (Santos and Frizzone, 2006).

The climatological normal temperature and relative humidity $(\mathrm{RH})$ in this region is $25.1{ }^{\circ} \mathrm{C}$ (February being the warmest month) and approximately $76.5 \%$, respectively. According to the State Secretariat of Water Resources and Irrigation (SERHI), this area has the rainy season from April to July, while the dry season is from October to January. The remaining months are considered as transition periods. Local climate is characterized as Tropical Rainy with dry summer. The rainy season begins in the fall. The average annual precipitation is 1,327 $\mathrm{mm}$ year $^{-1}$. The maximum rainfall in the region would be linked to the greater breeze circulation activity that causes cloud bands to the continent and the action of cold fronts, or their remnants, that propagate along the coast (Silva-Junior et al., 2005; Santos and Frizzone, 2006). This maximum would be associated with the maximum convergence of the trade with the land breeze, which should be stronger during the fall and winter seasons, when the temperature contrast between land and sea is greatest.

In the experimental area II was installed a micrometeorological tower 26 meters high $\left(10^{\circ} 17^{\prime}\right.$ $36^{\prime}$ 'S, $\left.36^{\circ} 17^{\prime} 24^{\prime} ' \mathrm{~W}\right)$, inserted into the forest fragment Micrometeorological in which measurements are performed.

Considering the depth levels for the study of ground temperature fluctuations (ST), thermal sensors called thermocouples were installed, from January to December 2010, to perform measurements at depths of $1,5,10,20,50 \mathrm{~cm}$. Thermocouple sensors are junction of two different metal wires that produce an electromotive force proportional to the difference in temperatures to which each of the pair's joints is subjected.

Rainfall totals were collected by model TE 525 rainfall gauges (Texas Instruments, USA). The pyranometers were installed at different levels and positions, around 2, 13 and 26 meters high, while the rain gauge was installed at the top of the tower.

\section{Wavelet Transform (WT)}

Because signals from natural systems such as ST have irregular characteristics or limited time, they are considered non-stationary. Therefore, a 
representation that follows the signal spectrum and time smoothing has been performed through the wavelet transform (WT). This tool is capable of detecting power variations within weather data.

The term wavelet refers to a set of waves formed by dilated $(\psi(t) \rightarrow \psi(2 t)]$ and translation $[\psi(t)$ $\rightarrow \psi(t+1)]$ of a single function $\psi(t)$, which is quadratically integrable over the field of real or space $[L 2(R)]$ and has finite energy. The function $\psi(t)$ can be called "mother wavelet", "Basic wavelet" or "analyzer wavelet", while dilated and transladadas functions derived from the mother wavelet are simply called "wavelets" (Weng and Lau, 1994).

$\psi_{l, t \prime}(t)=\frac{1}{\sqrt{l}} \psi\left(\frac{t-t^{\prime}}{l}\right)$

For $l$ and $t^{\prime} \in \mathbb{R}$ and $l \neq 0$.

Where $\psi(t)$ is the "mother wavelet", $l$ is the scale and the variation of this parameter involves the effect of dilation $(l>0)$ or contraction $(l<0)$ of the time series. Through this, one can analyze the aspects of long or short periods of the series, and $t^{\prime}$ is the translation parameter, that is, the location of the function in time.

In order to identify possible trends, cyclical periods, seasonal and random variation, the wavelet transform was used from the observational ST data for the depths of 1 or 2,20 and $50 \mathrm{~cm}$. The WT were submitted to the ST series of each biome, for the entire data period of the TS and rainfall with the intention of identifying trends, cycles or oscillations in the soil, during the different climatic and microclimatic conditions, in order to make comparisons between the seasons of the year and the biomes. These preliminary wavelet analyses can provide a clearer indication of the oscillations of the maximum and minimum temperatures of the soil throughout the series.

The choice of the "mother wavelet" was made in such a way that it has characteristics similar to the signal to be studied, such as asymmetry and sudden or mild variation in time. The Morlet wavelet was used, because according to Bolzan (2004), this methodology has characteristics similar to those of meteorological signals and is expressed by (Torrence and Compo, 1998):

$\psi(t)=\frac{1}{\sqrt[4]{\pi}} e^{i \omega_{0} t} e^{-\frac{t^{2}}{2}}$

where $\omega_{0}$ is the frequency and $t$ is the time.
In the wavelet energy spectrum (WES) statistically significant periodicities (with 95\% assurance) are delimited by continuous contour lines, which define a periodogram region called the cone of influence (COI) (U-shaped curve), The period outside this cone should not be considered as they lack statistical confidence. The regions outside this curve include the edge effects (boundary boundaries) of the series, which are responsible for undesirable effects. Therefore, only the spectra contained within the COI region are of interest. The Global Wavelength power (GWP) calculated from the variances (energies) associated with each of the periods of the series is important to verify the average contribution of the spectral peaks (Bolzan, 2004; Silva et al., 2009).

\section{Results and discussion}

\section{Amazon Forest}

Figure 2 shows a persistent and very homogeneous signal in the WES associated to the time scale of 24hours in all depth levels (Figure 2b i, ii and iii). It was also possible to observe in the GWP chart at all depths (Figure 2c i, ii and iii) an intense peak energy associated with the daily fluctuation, which is related to gains and losses of radiative energy along day, which shows little soil temperature fluctuation in the region. This $24 \mathrm{hr}$ oscillations show the same energy in all depths implying that the soil heating occurs simultaneously. A reduction was noticed in the energy starting on JD (Julian Day) 75 at $2 \mathrm{~cm}$ and JD 100 at the other depths; a small increase in energy occurred on JD 200, which may be clearly present in the ST variability index (Figure 2a i, ii e iii). The energy reduction in the wavelets for these days is related to the higher values of precipitation what is responsible for a decrease in the available radiative energy in the soil. It is also evident that larger wavelet energy changes occur starting from JD 250. This energy pattern is possibly due to stronger effect of the global solar radiation.

There are also cores in WES changing from 8 to 16 days, with high degree of persistence and homogeneity. The GWP associated with this periodicity ( 8 a 16 days) as well as the daily oscillation show an intense energy peak. It is noted that the layer of $2 \mathrm{~cm}$ had the highest concentration of energy and there is a slight reduction of energy between the layers 20 and $50 \mathrm{~cm}$. This reduction is more evident at the beginning of the year (between the JD 50 and 100), and may be related to lower soil heat flux for this period. 


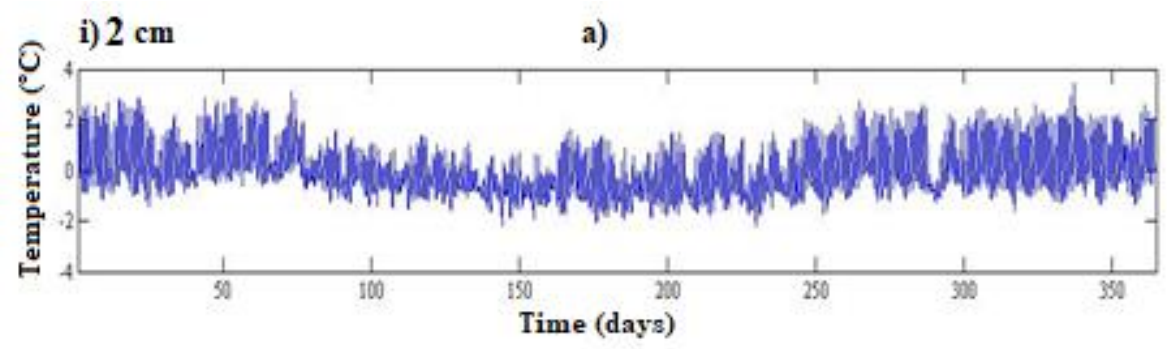

b)
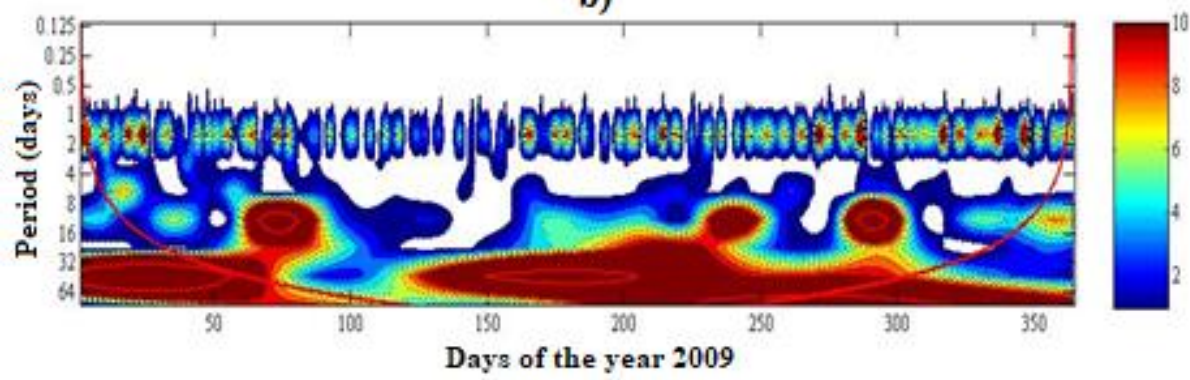

c)

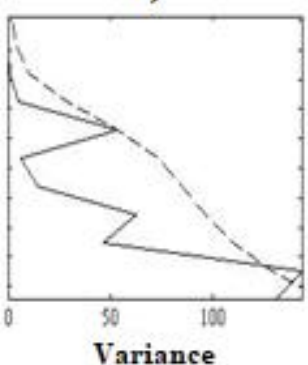

ii) $20 \mathrm{~cm}$

a)

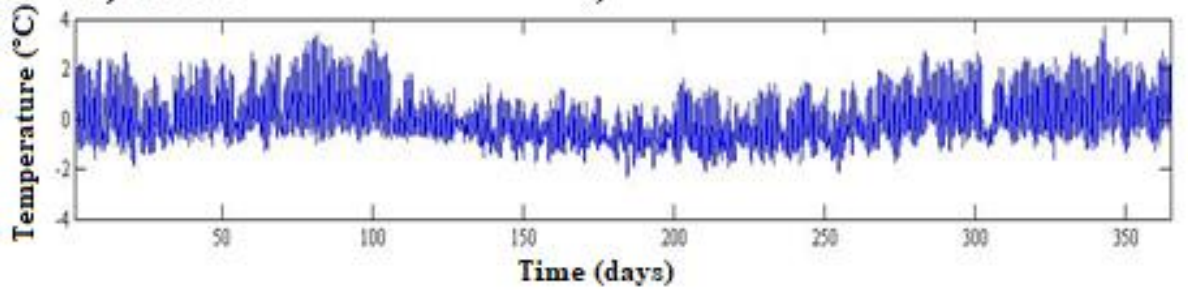

b)

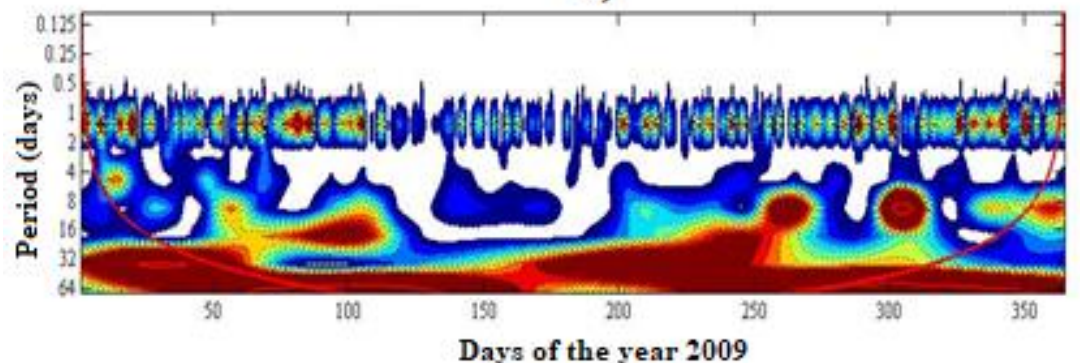

c)
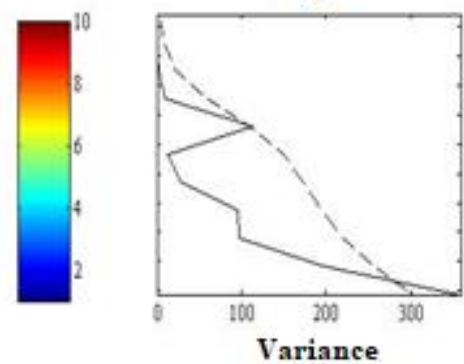

iii) $50 \mathrm{~cm}$

a)

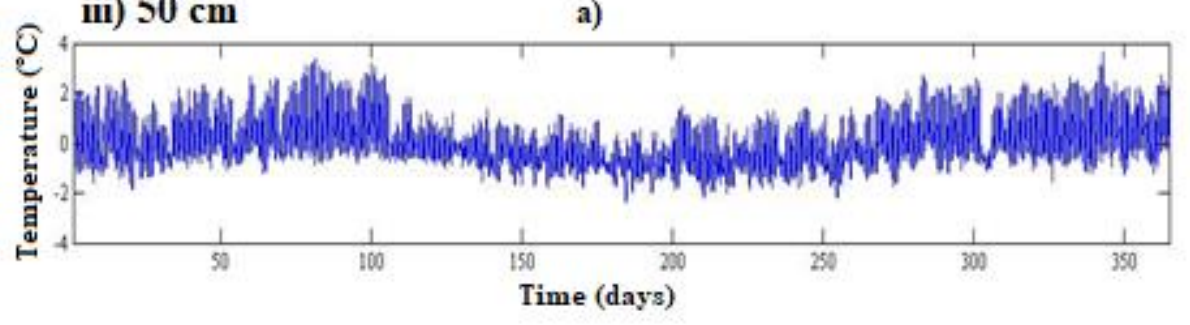

b)
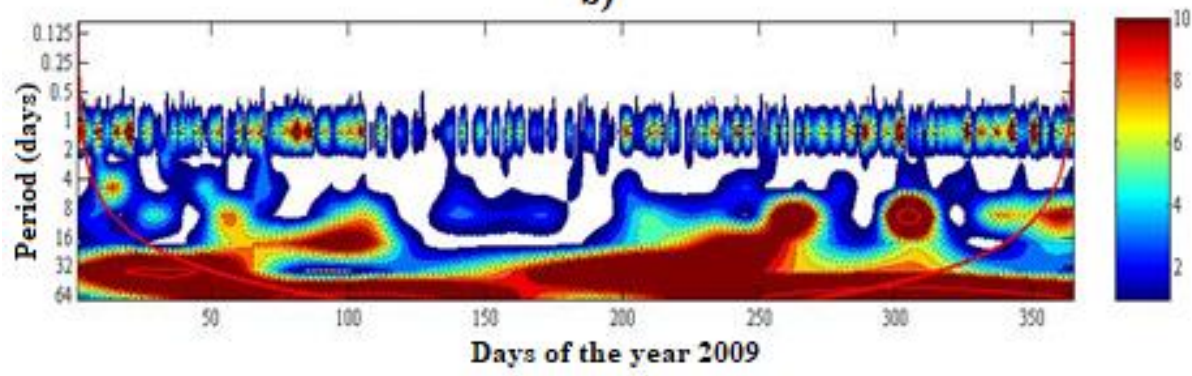

c)

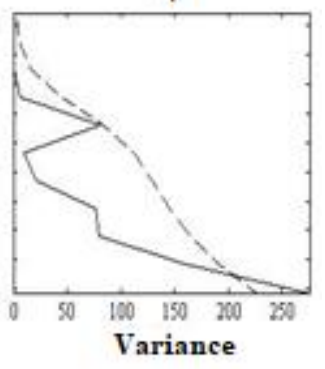

Figure 2 - ST variability index (a), wavelet energy spectrum (WES) (b) and global wavelet power (GWP) (c), at depths of $2 \mathrm{~cm}$ (i), $20 \mathrm{~cm}$ (ii) and $50 \mathrm{~cm}$ (iii) for the same variable and depths in the Amazon Forest. 
This oscillation ( 8 to 16 days) is associated with water on the soil resulted from previous precipitation and the evaporative process that renders the soil to have a significantly increased heat capacity. The energy source is the evaporative process and the overall increase in its intensity, due to the surface solar radiation produce a change in the kinetic energy of water molecules. Consequently, after evaporation, this radiative energy is responsible by the increase ST (Cai et al., 2009).

There is also an oscillation between 2 and 4 days, with cores at 8 to 16 days, which is also related to the amount of water in the soil. However, this oscillation differs from the above mentioned with the associated GWP, with little power, since it occurs only among the JD 1-90 and 300-365.

Another energy peak in ST was detected with periods between 32 to 64 days being possible to notice a larger signal at $2 \mathrm{~cm}$ deep and similar signal in the layer 20 and $50 \mathrm{~cm}$. This periodicity occurs only between JD $125-250$ because the peaks found in the beginning and end of the year are outside the cone of influence (COI) of the periodogram ( $\mathrm{U}$ shaped curve in red) in Figures $2 b$ i, ii and iii. As previously stated periods outside the cone should not be considered. This maximum power can be associated with a single event.

The soil temperature profile (ST) it was observed that it presented a small thermal amplitude $\left(1.1^{\circ} \mathrm{C}\right)$ (Figure 3). The small amplitudes may be attributed to the dense vegetation cover (canopy and secondary forest) which reduces the soil heat inflow and to the emission of long wave radiation into the overlying atmosphere (Paul et al., 2004; Oliveira et al., 2008). Another reason for these small amplitudes to occur is the large layer of litter on the Amazon soil, which besides protecting the soil against moisture loss, also favors the formation of humid microclimate, serving as a water reservoir for growing plants and functioning as a thermal insulator (Luizão, 2007).

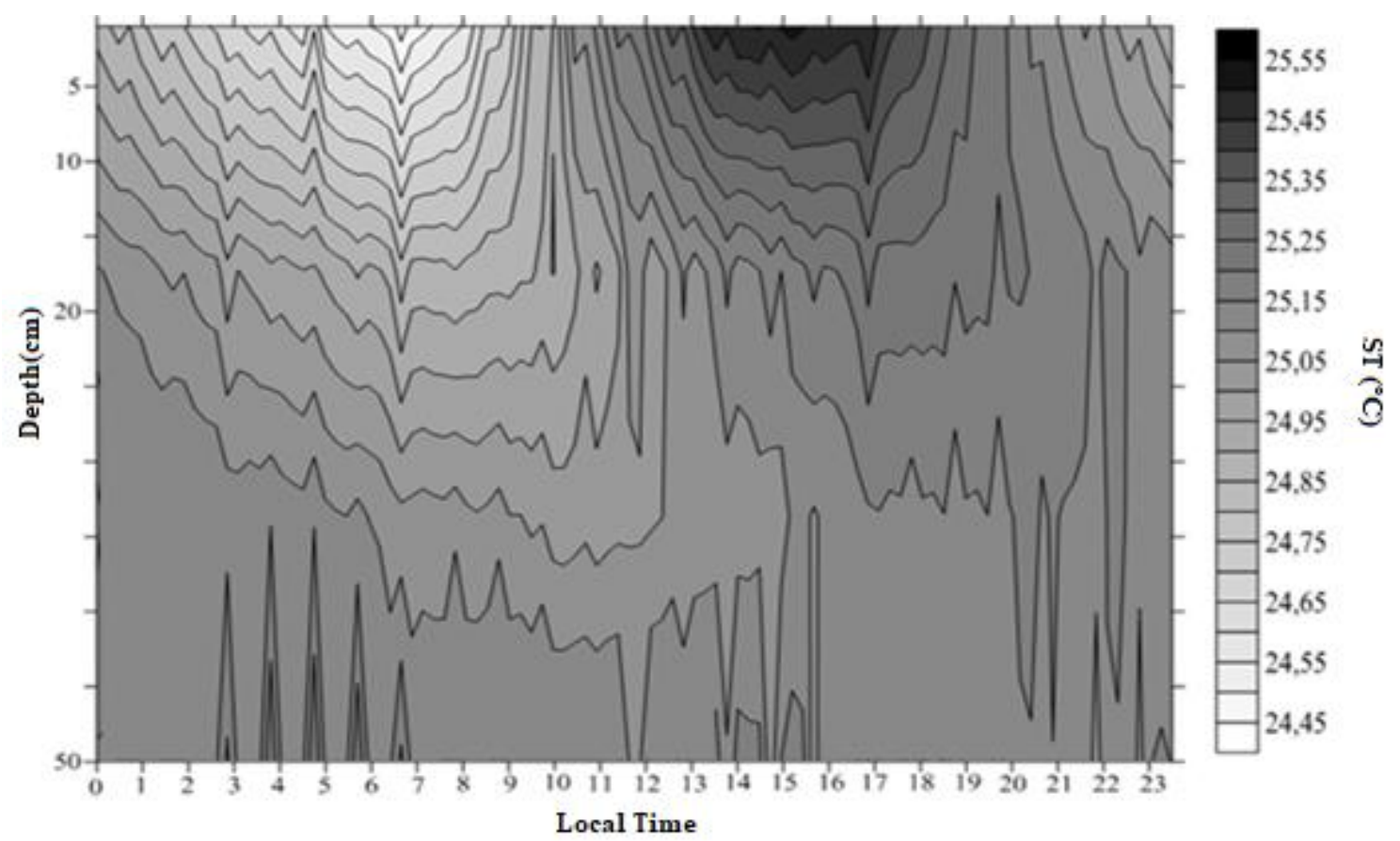

Figure 3 - Profile of hourly average soil temperatures (ST) $\left({ }^{\circ} \mathrm{C}\right)$ in the Amazon forest for 2009.

Smaller ST were recorded in the early hours of the day, with a minimum of $24.45^{\circ} \mathrm{C}$ at $07 \mathrm{LT}$ (Local Time) for the $2 \mathrm{~cm}$ level. During this time, the ST increased by $0.05^{\circ} \mathrm{C} \mathrm{cm}^{-1}$ with depth reaching a maximum of $25.15{ }^{\circ} \mathrm{C}$ in $50 \mathrm{~cm}$ level. This thermal fluctuation during the night time is related to radiative cooling.

From 09 LT onward, ST increases in all layers in response to the positive heat flow into the soil. It was observed between 13 and 17 LT larger ST in the layers 2 and $5 \mathrm{~cm}$ layer, with a maximum of $25.55^{\circ} \mathrm{C}$ at $15 \mathrm{LT}$ for $2 \mathrm{~cm}$ deep. This thermal regime is determined by the heating of the surface due to the incident solar radiation and slow and gradual conduction of sensible heat into the soil (Silva-Júnior et al., 2005). In the subsequent layers the ST presented a decrease of $0.05^{\circ} \mathrm{C}$.

It was possible to observe up to $10 \mathrm{~cm}$ depth the largest variations of the ST throughout the day. While, $50 \mathrm{~cm}$ deep ST remained practically constant throughout the study. This thermal behavior, according to Oliveira et al. (2010), occurs because the ST is controlled by the daily periodization of the soil heating and, therefore, causing more prominent variations of the ST in the first layers and stabilizing in the deeper layers. 
When analyzing the precipitation by WT in the Amazon Forest (Figure 4), it is possible to observe sparse and intermittent peaks with conical structures, characteristic of this variable (Moura et al., 2014). However, these conical structures are observed almost throughout the study year, due to the high rainfall of the region. There is also a higher concentration between JD 1 to 150 , showing an increase in the wavelet signal from JD 45 (Figure
4B). This result confirms the fact that the reduction of the wavelet energy in the daily ST oscillation, as shown in Figure 2B i, ii and iii, is due to the increase of this energy for precipitation. It was also found that from JD 200 the wavelet energy spectrum began to show its lowest values and variability indices (Figure 4A), proving that from that date the highest energy values for ST in region.

a)

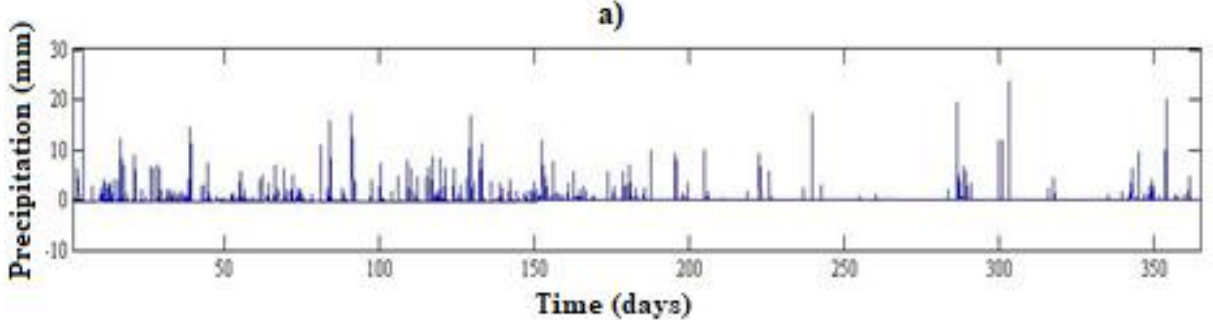

b)

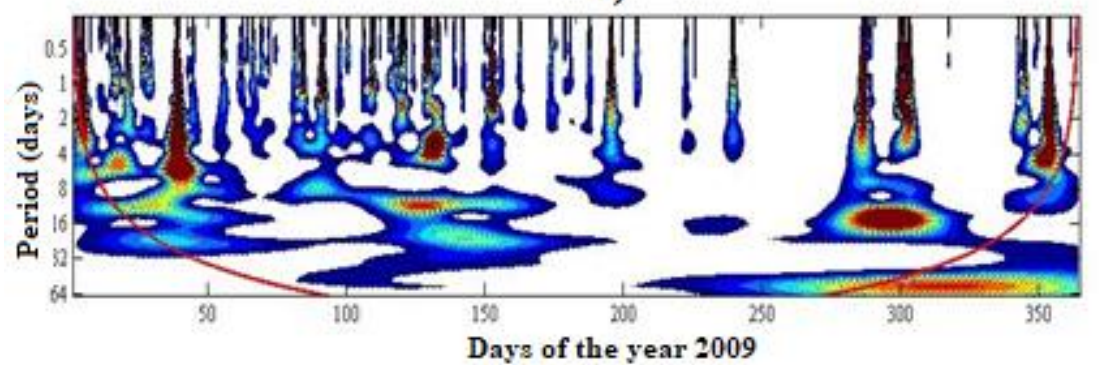

c)

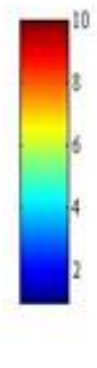

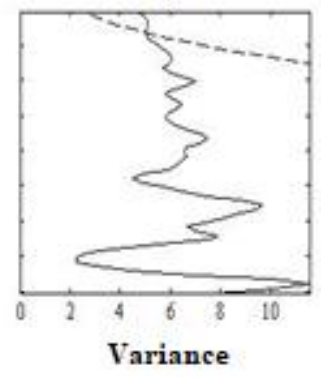

Figure 4 - Precipitation variability index (a), wavelet energy spectrum (WES) (b) and Global wavelet power (GWP) (c) in the Amazon Forest.

It was found in the WES for the precipitation series, core in the scale ranging from 8 to 16 days; their associated GWP having highest energy (Figure 4c). The core occur between 30 and 40 JD (January 30 to February 9), 120 and 135 (April 30 to May 15) and 280-300 (7 to October 27). This confirms that higher precipitation energies preceded the higher energy nuclei of ST for this oscillation.

\section{Atlantic Forest}

In the Atlantic forest, as in the Amazon, the signal on the 24-hour timescale of the energy spectrum with very homogeneity at all depths was identified (Figures 5b i, ii and iii). There is an intense energy peak in the GWS associated with this periodicity (Figure 5c i, ii and iii). However, for the depth of $1 \mathrm{~cm}$ (Figure 5C i) this maximum energy is more pronounced than the other depths, because this oscillation is due to solar energy gains and losses and causes greater variation in energy exchanges. This difference may be related to the inhomogeneity of the region's soil as described by Carneiro et al. (2014).

It was also noticed a reduction in the energy from JD 150 (depth of $1 \mathrm{~cm}$ ) and JD 175 (depths of 20 and $50 \mathrm{~cm}$ ). Increased values were observed at different depths and dates: JD $250(1 \mathrm{~cm})$, JD 260 (20 $\mathrm{cm})$ and JD $270(50 \mathrm{~cm})$ (Figure 5a I, ii and iii). This time interval coincides with the rainy season what explains the reduction in the wavelet energy.

A core in the WES ranging from 4 to 16 days was observed, with a high degree of homogeneity and persistence and the associated GWP having high energy can be observed in Figure $5 \mathrm{~b}$ ci, ii and iii. Unlike what was analyzed on the daily scale, this oscillation showed that the $1 \mathrm{~cm}$ level has lower energy concentrations and a significant increase of energy in the 20 and $50 \mathrm{~cm}$ layer. This reduction is more evident during the JD 130-250, which may be related to the water content in the soil by this time of year, thus reducing the amount of energy reaching the most superficial layer.

The variability (4-16 days), as discussed for the Amazon region, is the result of a subsequent evaporation of the water in the soil and precedes these higher rates of energy rain period. Regarding the range of variability, this fact contrasts with the Amazon oscillation because the Atlantic Forest region has lower rainfall, which renders these power peaks to occur at longer intervals. 


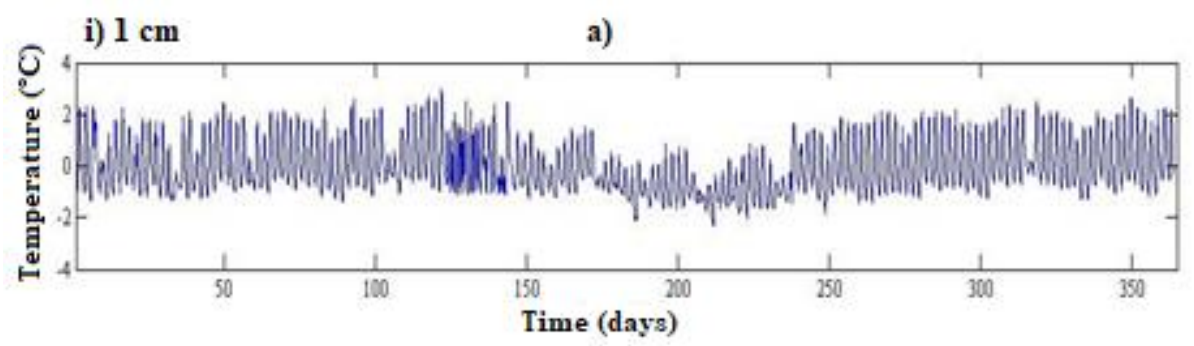

b)
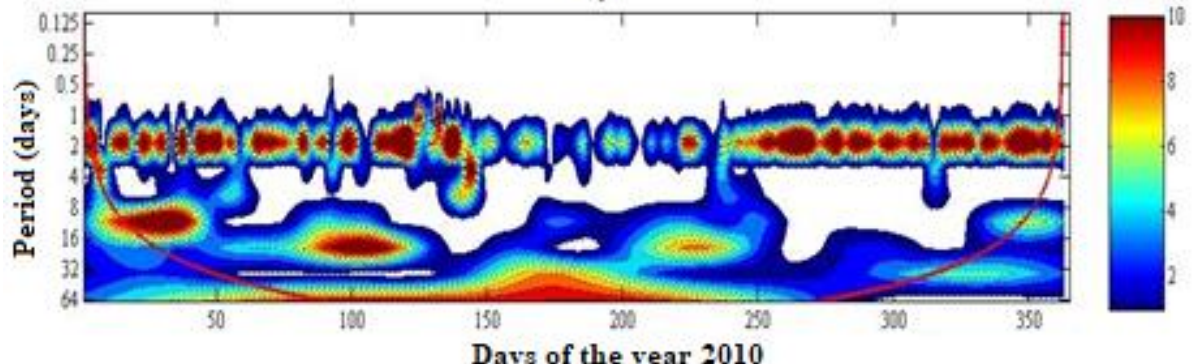

c)

ii) $20 \mathrm{~cm}$

a)

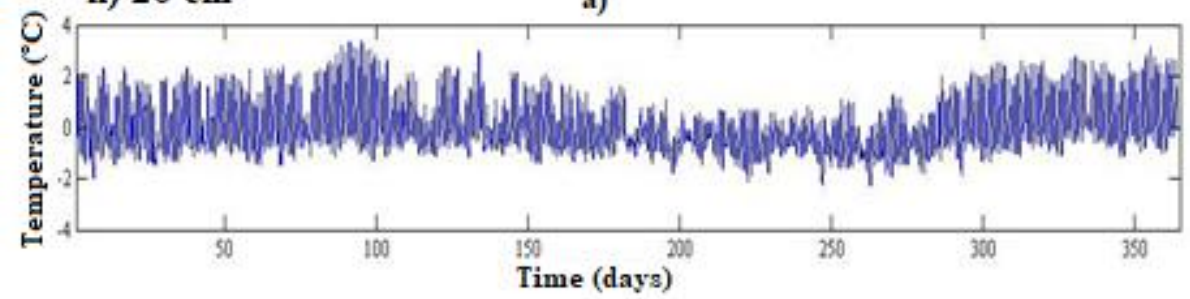

b)
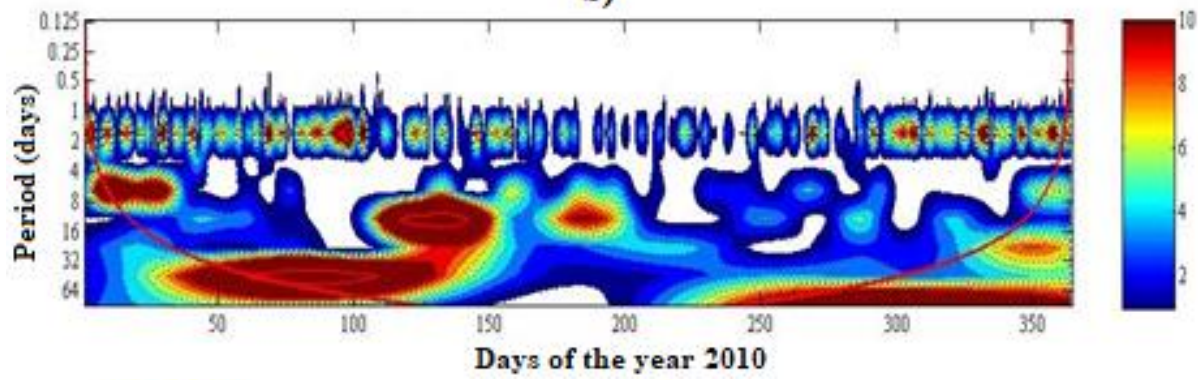

c)

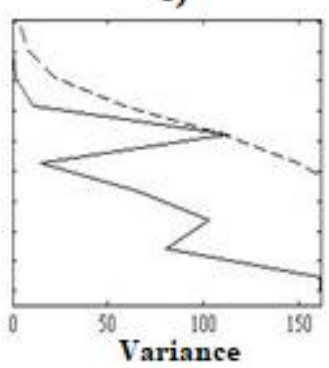

iii) $50 \mathrm{~cm}$

a)

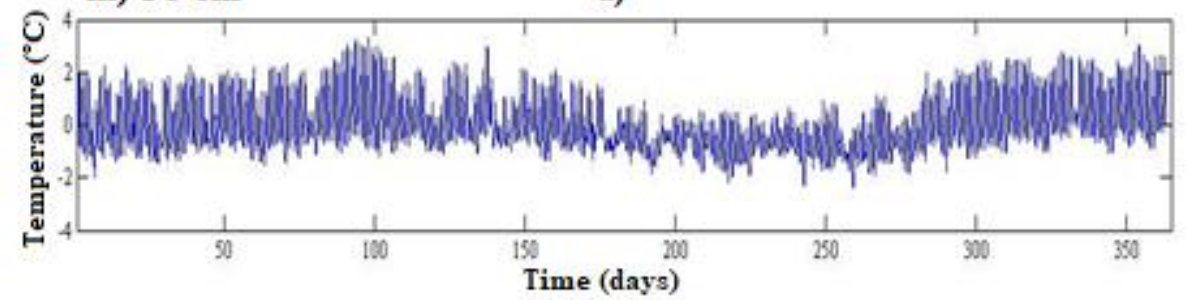

b)

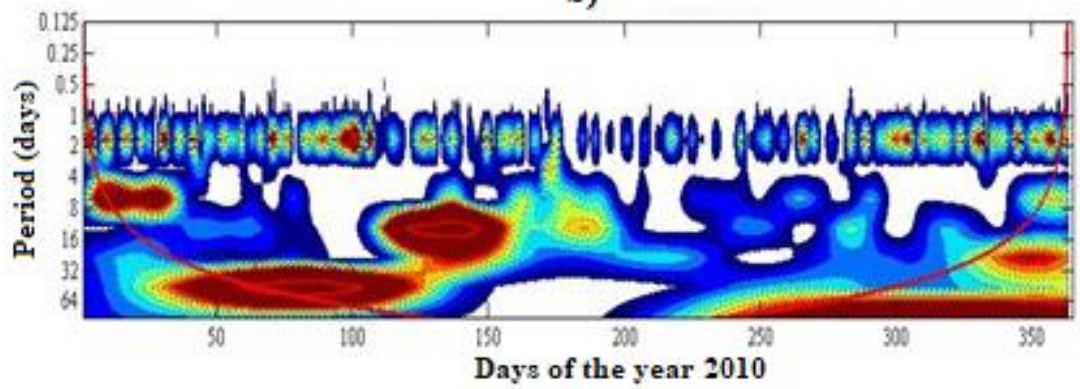

c)
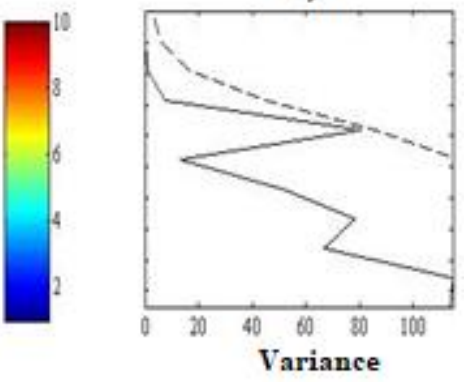

Figure 5 - ST variability index (a), wavelet energy spectrum (WES) (b) and global wavelet power (GWP) (c), at depths of $1 \mathrm{~cm}$ (i), $20 \mathrm{~cm}$ (ii) and $50 \mathrm{~cm}$ (iii) for the same variable and depths in the Atlantic Forest. 
Also was detected wobble ranging between 32 and 64 days, with defined nuclei related to the amount of water in the soil. However, this GWP is presented with low energy in the $1 \mathrm{~cm}$ layer and increase in the following layers. The periods are between JD 50 to 120 and JD 200 and 250 at depths of 20 and $50 \mathrm{~cm}$, with a strong WES, at the same time, this oscillation at $1 \mathrm{~cm}$ deep has less intense core.
Figure 6 shows a spatial and temporal thermal amplitude of $12{ }^{\circ} \mathrm{C}$ in the ST profile. This greater thermal amplitude in relation to the area of the Amazon rainforest is possibly related to the fact that the crown of the tree canopy is not so dense and high and has clearings in its vegetative canopy. This allows for more intense radiative heat transfer fluxes from the atmosphere to the ground, as well as the greatest energy loss from longwave radiation.

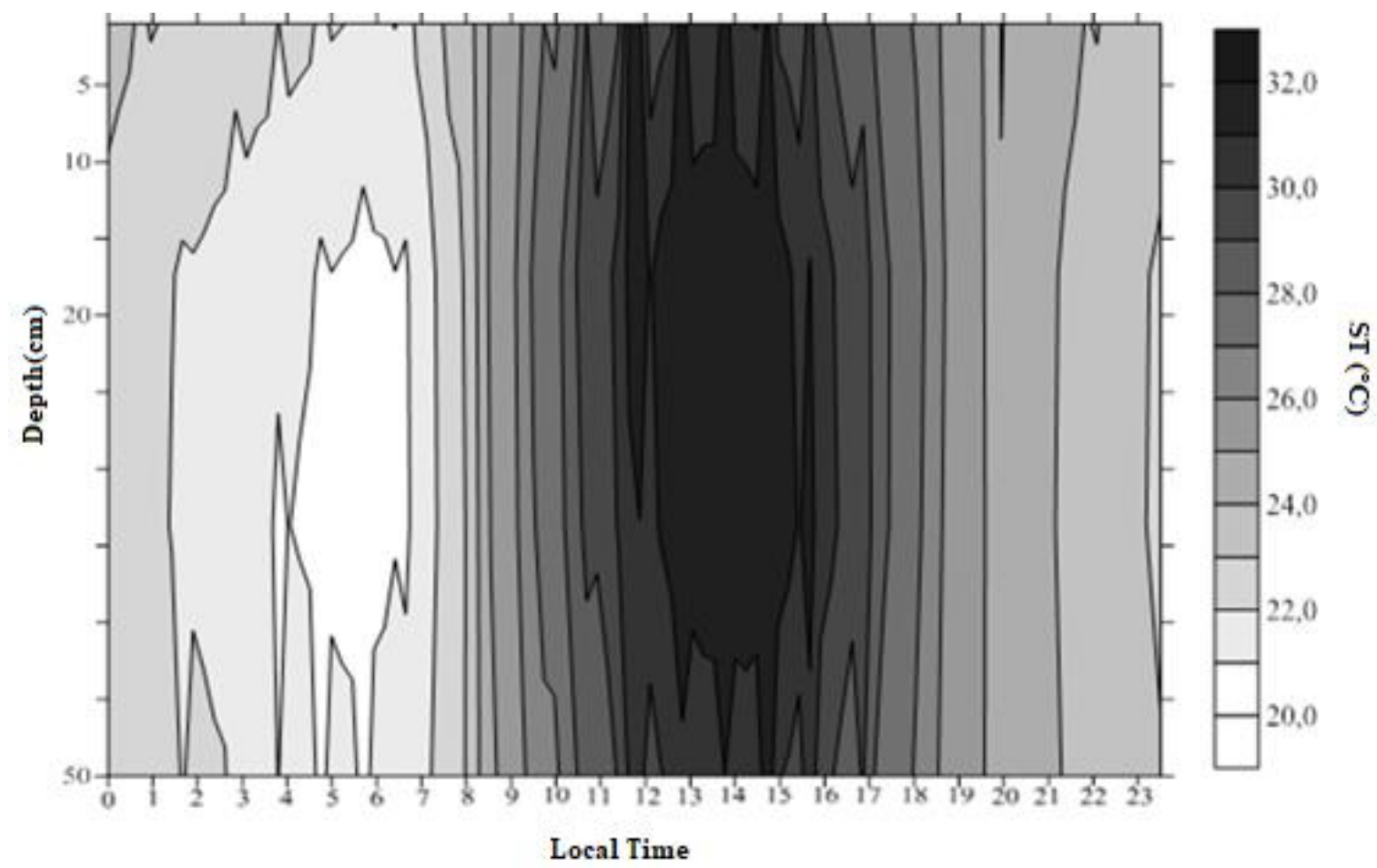

Figure 6 - Profile of hourly average soil temperatures (ST) $\left({ }^{\circ} \mathrm{C}\right)$ in the Atlantic forest for 2010.

Were recorded in the early hours $(02-07$ LT) smaller ST, remaining constant from the surface to $10 \mathrm{~cm}\left(21{ }^{\circ} \mathrm{C}\right)$ it was observed a reduction of $1{ }^{\circ} \mathrm{C}$ in the following layers, causing a minimum of $20^{\circ} \mathrm{C}$ (05 and $06 \mathrm{LT}$ ) in the $20 \mathrm{~cm}$ deep.

From 09 LT ST begins to show a thermal increase at all depths. It was observed between 12 and $16 \mathrm{LT}$ the largest records, which remained practically constant between 1 and $10 \mathrm{~cm}$ deep with values of $30^{\circ} \mathrm{C}$ and with some variations in time. An increase of $2{ }^{\circ} \mathrm{C}$ at the $20 \mathrm{~cm}$ level, resulting a maximum value of temperature of $32{ }^{\circ} \mathrm{C}$ corroborates with the larger energy registered in this layer than in the superficial layers, as shown by the WT analysis. At $50 \mathrm{~cm}$ depth the ST has a reduction of $2{ }^{\circ} \mathrm{C}$, returning the temperature of the superficial layers.

The WT for precipitation in the Atlantic Forest (Figure 7) presented differences in relation to the Amazon region, with peaks concentrated in only one period of the year, between JD 50 and 200, because the region does not have rainfall throughout the year (Carneiro et al., 2014). It was found that the largest signal of the wavelet was located between the JD 90 to 200 (Figure 7b), causing the energy reduction in the daily cycle of ST. From JD 1 to 50 and from JD 200 to 365 the wavelet energy spectrum and variability indices are almost null (Figure 7a) at these dates ST has its highest energies.

It was also noted that precipitation exhibited core of the wavelet energy spectrum ranging from 4 to 16 days, for this variability GWP exhibits its highest values (Figure 7c). These cores preceded the oscillation maximums for ST, as observed in the Amazon. This also confirms that the ST periodicity of 32 to 64 days is correlated with evaporation, with precipitation cores occurring between JD 40 to 50 and 130 to 200. 


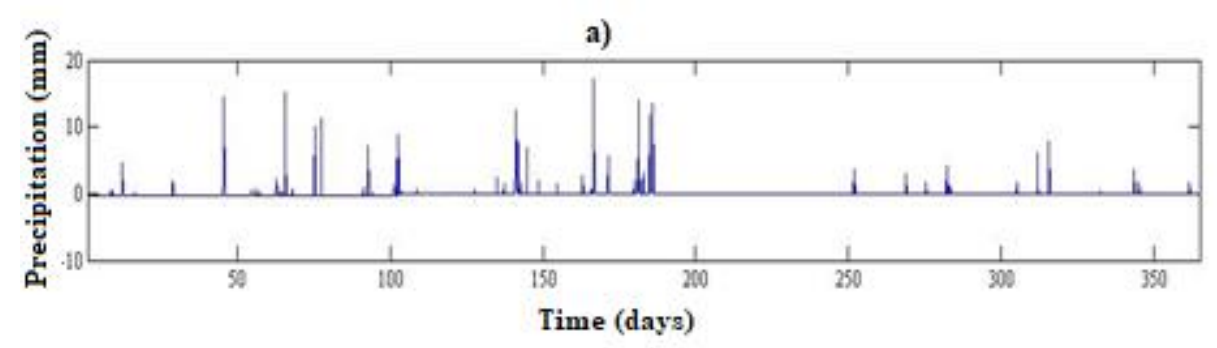

b)

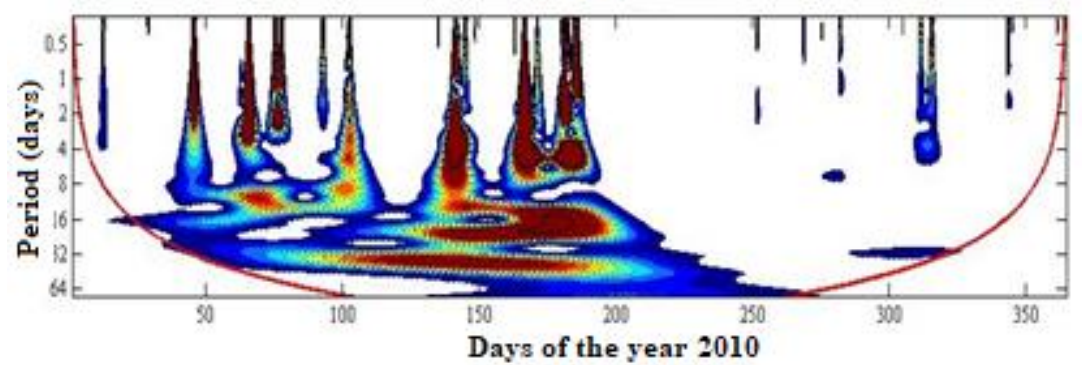

c)

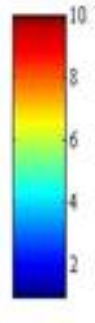

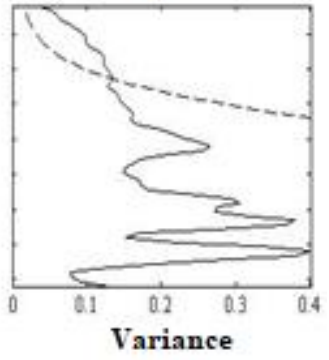

Figure 7 - Precipitation variability index (a), wavelet energy spectrum (WES) (b) and global wavelet power (GWP) (c) in the Atlantic Forest.

\section{Conclusions}

In this study we identified that the soil temperature has quite distinct patterns among the studied biomass. In the Amazon Rainforest, ST has low thermal amplitude (below $2{ }^{\circ} \mathrm{C}$ ) temporal and spatial. Already in the Atlantic Forest the ST has high thermal amplitude $\left(12{ }^{\circ} \mathrm{C}\right)$.

Through the transformation into wavelets it was verified that the soil temperature variability in the forest regions is defined by temporal multi-scales.

The Amazon Forest had three observed periodicities, two with a high degree of persistence, homogeneity and high energy, in the 24 hour and 8 to 16 day scales. And one with low associated energy ranging from 2 to 4 days.

While the Atlantic Forest presented two oscillations with a high degree of persistence, homogeneity and high energy in the daily scales and from 4 to 16 days. In both regions the oscillations were in phase with the cycles of precipitation.

\section{Acknowledgements}

The authors thank CNPq (National Council for Scientific and Technological Development) for funding this study, the National Institute for Research in the Amazon (INPA) and the Sugar and Ethanol Coruripe S/A factory.

\section{References}

Awe, G.O., Reichert, J.M., Wendroth, O.O., 2015. Temporal variability and covariance structures of soil temperature in a sugarcane field under different management practices in southern Brazil. Soil \& Tillage Research 150, 93-106.

Bolzan, M.J.A., 2004. Análise da transformada em ondeletas aplicada em sinal geofísico. Revista Brasileira de Ensino de Física 26, 37-41.

Cai, J.B., Liu, Y., Xu, D., Paredes, P., Pereira, L.S., 2009. Simulation of the soil water balance of wheat using daily weather forecast messages to estimate the reference evapotranspiration. Hydrology and Earth System Sciences 13, 10451059.

Carneiro, R.G., Moura, M.A.L., Andrade, A.M.D., 2013. Variação da temperatura do solo em fragmento de Mata Atlântica em Coruripe-Al Um estudo de caso. Caminhos da Geografia 14, 139-149.

Carneiro, R.G., Moura, M.A.L., Silva, V.P.R., Silva Junior, R.S., Andrade, A.M.D., Santos, A.B., 2014. Variabilidade da temperatura do solo em função da liteira em fragmento remanescente de mata atlântica. Revista Brasileira de Engenharia Agrícola e Ambiental 18, 99-108.

Chellali, F., Khellaf, A., Belouchrani, A., 2010. Wavelet spectral analysis of the temperature and wind speed data at Adrar, Algeria. Renewable Energy 35, 1214-1219.

Freitas, M.D., Castro Júnior, W.E., 2004. O ciclo hidrológico: projeções mundiais e Amazônia, in: Freitas, M.D. (Eds.), Amazônia e Desenvolvimento Sustentável: um diálogo que todos deveriam conhecer. Vozes/Editora, Petrópolis, pp. 65.

Graham, E.A., Lam, Y., Yuen, E.M., 2010. Forest understory soil temperatures and heat flux calculated using a Fourier model and scaled using 
a digital camera. Agricultural and Forest Meteorology 150, 640-649.

INPE. Instituto Nacional Pesquisas Espaciais, 2016. Projeto PRODES: monitoramento da floresta Amazônica Brasileira por satélite. Disponível: http://www.obt.inpe.br/prodes/. Acesso: 24 mar. 2017.

INPE/SOS Mata Atlântica - Instituto Nacional Pesquisas Espaciais, 2016. Atlas dos Remanescentes Florestais da Mata Atlântica no período de 2014 a 2015. Disponível: https://www.sosma.org.br/projeto/atlas-da-mataatlantica/dados-mais-recentes/. Acesso: 10 abr. 2017.

Ledru, M.P., Rousseau, D.D., Cruz Jr., F.W., Riccomini, C., ,Karmann, I., Martin, L., 2005. Paleoclimate changes during the last $100,000 \mathrm{yr}$ from a record in the Brazilian Atlantic rainforest region and interhemispheric comparison. Quaternary Research 64, 444-450.

Luizão, F.J., 2007. Ciclos de nutrientes na Amazônia: respostas às mudanças ambientais e climáticas. Ciência e Cultura (SBPC) 59, 31-36.

Malhi, Y., Pegoraro, E., Nobre, A.D., Pereira, M.G.P., Grace, J., Culf, A.D., Clement, R., 2002. Energy and water dynamics of a central Amazonian rain forest. Journal of Geophysical Research 107, 1-17.

Marques Filho, A.D.O., Dallarosa, R.G., Pacheco V.B., 2005. Radiação solar e distribuição vertical de área foliar em floresta - Reserva Biológica do Cuieiras - ZF2, Manaus. Acta Amazônica 35, 427-436.

Moura, M.A.L., Deodato, A.F., Carneiro, R.G., 2014. Estudo dos padrões climatológicos do vento usando transformada em ondeletas. Revista Brasileira de Geografia Física 7, 774-783.

Oliveira, A.N., Amaral, I.L., Ramos, M.B.P., Nobre, A.D., Couto, L.B., Sahdo, R.M., 2008. Composição e diversidade florístico-estrutural de um hectare de floresta densa de terra firme na Amazônia Central, Amazonas, Brasil. Acta Amazônica 38, 627-642.

Oliveira, S.S., Fideles Filho, J., Oliveira, S.V., Araújo, T.S., 2010. Difusividade térmica do solo de campina grande para dois períodos do ano. Revista de Geografia 27, 179-189.

Onwuka, B.M., 2016. Effects of soil temperature on Some Soil properties and plant growth. Journal of Agricultural Science 6, 89-93,
Park, K., Yang, H., Lee, B.Y., Kim, D., 2018. Development of Shallow-Depth Soil Temperature Estimation Model Based on Thermal Response in Permafrost Area. Applied Sciences 8, 1-17.

Paul, K.I., Polglase, P.J., Smethurst, P.J., O'connell, A.M., Carlyle, C.J., Khanna, P.K., 2004. Soil temperature under forests: a simple model for predicting soil temperature under a range of forest types. Agricultural and Forest Meteorology 121, 167-182.

Qian, B., Gregorich, E.G., Gameda, S., Hopkins, D.W., Wang, X.L., 2011. Observed soil temperature trends associated with climate change in Canada. Journal of Geophysical Research 116, 1-16.

Santos, M.A.L., Frizzone, J.A., 2006. Irrigação suplementar da cana-de-açúcar (saccharum spp) colhida no mês de janeiro: um modelo de análise de decisão para o litoral sul do estado de alagoas. Irriga 11, 339-355.

Silva, D.F., Sousa, F.A.S., Kayano, M.T., 2009. Uso de IAC e ondeletas para análise da influência das multi-escalas temporais na precipitação da bacia do Rio Mundaú. Revista Engenharia Ambiental 6, 180-195.

Silva-Júnior, R.S., Moura, M.A.L., Meixner, F.X., Kormann, R., Lyra, R.F.F., Nascimento-Filho, M.F., 2005. Estudo da concentração do $\mathrm{CO}_{2}$ atmosférico em área de pastagem na região amazônica. Revista Brasileira de Geofísica 22, 605-611.

Torrence, C., Compo, G.P., 1998. A practical guide to wavelet analysis. Bulletin of the American Meteorological Society 79, 61-78.

Wang, W., Rinke, A., Moore, J.C., Ji, D., Cui, X., Peng, S., Lawrence, D.M., Mcguire, A.D., Burke, E.J., Chen, X., Decharme, B., Koven, C., Macdougall, A., Saito.K., Zhang, W., Alkama, R., Bohn, T.J., Ciais, P., Delire, C., Gouttevin, I., Hajima, T., Krinner, G., Lettenmaier, D.P., Miller, P.A., Smith, B., Sueyoshi, T., Sherstiukov, A.B., 2016. Evaluation of air-soil temperature relationships simulated by landsurface models during winter across the permafrost region. The Cryosphere 10, 1721-1737.

Weng, H., Lau, K.M., 1994. Wavelets, Period Doubling, and Time-Frequency Localization with Application to Organization of Convection over the Tropical Western Pacific. Journal of the Atmospheric Sciences 51, 2523-2541. 